\title{
HOW TO TEACH ENGLISH ENTRANT FOR BINUS UNIVERSITY STUDENTS \\ USING A CELL GROUP METHOD SUPPORTED BY BINUSMAYA
}

\author{
Melania Wiannastiti \\ English Department, Faculty of Humanities, BINUS University \\ Jln. Kemanggisan Ilir III No 45, Kemanggisan, Palmerah, Jakarta Barat 11480 \\ Mwiannastiti@Binus.Edu; Senthita@Yahoo.Com
}

\begin{abstract}
Teaching English Entrant, the first level of General English lecture for BINUS University students, needs a specific method because normally the number of students in one class is more than 50 students. Besides, the four skills of language and business communication have to be taught simultaneously in one semester. This paper is aimed to describe one method used at BINUS University to teach English Entrant classes: Cell Group method which students are divided into cell groups. This method is supported by Binusmaya, an online resource used in teaching learning at BINUS University. Through this resource, each member of the cells has the opportunity to access Binusmaya forum where he/she can upload, download, share and discuss material or problems raised. Each cell is also responsible to write reports about its activities. Based on the reports, the teacher who has a role as a moderator and source in both Binusmaya forum and classroom has to lead the cells discussion in the classroom.
\end{abstract}

Keywords: english entrant, big classes, cell group, Binusmaya, activities

\begin{abstract}
ABSTRAK
Mengajar English Entrant, level pertama dalam kuliah General English untuk mahasiswa BINUS University, membutuhkan metode tersendiri karena biasanya kelas berisi lebih dari 50 mahasiswa. Selain itu, empat keahlian bahasa dan komunikasi bisnis harus diajarkan pada waktu yang bersamaan dalam satu semester. Tulisan ini bertujuan untuk mendeskripsikan satu metode yang digunakan BINUS University untuk mengajar English Entrant, yaitu metode cell-group, yang membagi mahasiswanya dalam beberapa grup. Metode ini didukung oleh Binusmaya, sarana online yang digunakan dalam kegiatan pembelajaran dan pengajaran di BINUS University. Melalui penelitian ini, setiap anggota dalam grup memiliki kesempatan untuk mengakses forum Binusmaya agar mereka bisa mengunggah, mengunduh, membagi atau mendiskusikan materi atau permasalahan. Setiap grup bertanggung jawab untuk menulis laporan tentang aktivitas mereka. Berdasarkan laporan tersebut, dosen, yang memiliki peran sebagai moderator dan sumber dalam Binusmaya forum dan ruang kelas, harus memimpin grup-grup tersebut berdiskusi dalam ruang kelas.
\end{abstract}

Kata kunci: English entrant, kelas besar, grup, Binusmaya, aktivitas 


\section{INTRODUCTION}

Teaching English for university students needs different method for the high school ones, especially when the number of students is more than 50 and the four skills of language have to be taught in a limited time. It cannot be denied that lecturers hope that they teach small classes as it is stated by Richards \& Renandya (2002) that Most of teachers find themselves working with a class of fifty students or more and to make the matters worse, these students often exhibit a wide variety of abilities. On facing the type of the situation, lecturers need to think carefully to find the most suitable method to be used in teaching big classes.

There are many methods suggested by some experts but none is fully suitable for teaching big classes. One method called teacher-centered method is easy to be used in the big classroom but Richards \& Renandya (2002) said: "Too largely classes ignore individual differences and the contribution of the learners in learning process" (p. 49). Therefore this method is not suitable for big classes. Teachers need a method to be applicable in the big classrooms in which learners have contribution in the learning process and their individual differences are accepted as a part of a learning process.

Some of BINUS University lecturers have the same problem and challenge on how to handle big classes since the university offers lectures of General English called English Entrant, In Focus and Savvy where classes vary from 40-70 students. Lecturers have to improve students' skills in listening, reading, speaking, and writing in a limited time to reach a certain level of English with IBT TOEFL Test as the standard of passing grade. Therefore, lecturers need to find or modify methods to teach the big class effectively. Based on the reason, this paper will describe one method used in the university in teaching big classes English called English Entrant. It will also describe the students' activities during a semester they joined English Entrant as well as the advantages of the modified method.

\section{Theoretical Framework}

This paper is grounded on some methods suggested by experts to be used in the classroom such as audio-lingualism in which it uses Stimulus-Response-reinforcement model to engender good habits in language learners (Harmer, 2001). Another method suggested by Hammer is the Communicative Approach. It is a guiding principle to train students to use language form appropriately in variety of context and for a variety of purposes (Harmer, 2001). In this context, students are asked to be able to communicate to others using the targeted language. Both of the method can be combined to teach big classes. However, these methods do not cover all the skills in limited time. Teachers have no enough time checking students progress one by one if the students are more than 50 .

One other method suggested by Jacobs \& Hall (2002) which is used mostly in this paper is called Cooperative Learning. This method does not only mean putting students in group and have something to do but it is a tool teachers use to encourage mutual helpfulness in the group and the active participation of all members (p. 52). This method also enables teachers to give some tasks to do in the group in which each of the member in a group help one another to develop their English skills better as it can be said as a TEAM which is derived from Together Each Achieve More. By using this idea, students are grouped in four or five called Cell Group. They are hoped to do some activities together in the cell group and share ideas as well as practice their English skills. Students are situated in which s/he as a member of the group gets the opportunity to develop him/herself in the group and helps others to develop themselves too. 
A good method needs a good support. If teachers choose one method suitable for the classroom, they will need some media used in language teaching and learning. These media will help teachers and students to reach the objectives of the teaching learning. Nowadays, thousand of media are available to be used by teachers in language and teaching especially through the websites on the internets. According to Li and Hart stated in Richards \& Renandya (2002) the internet possesses a number of features which particularly suited second language learners' growing proficiency in language. Therefore the internet enables teachers to find more variety in language teaching and supporting the method they choose.

One medium of the Internet used in this paper is Binusmaya (as in Figure 1). It is a website provided by the university for the lecturers and students to communicate. For lecturers, it provides schedule, material for teaching, detail information and Binusmaya forum in which they can communicate with the active students in the lectures they teach in a certain semester. For students, it provides all information about their study including the lectures they take in the active semester.

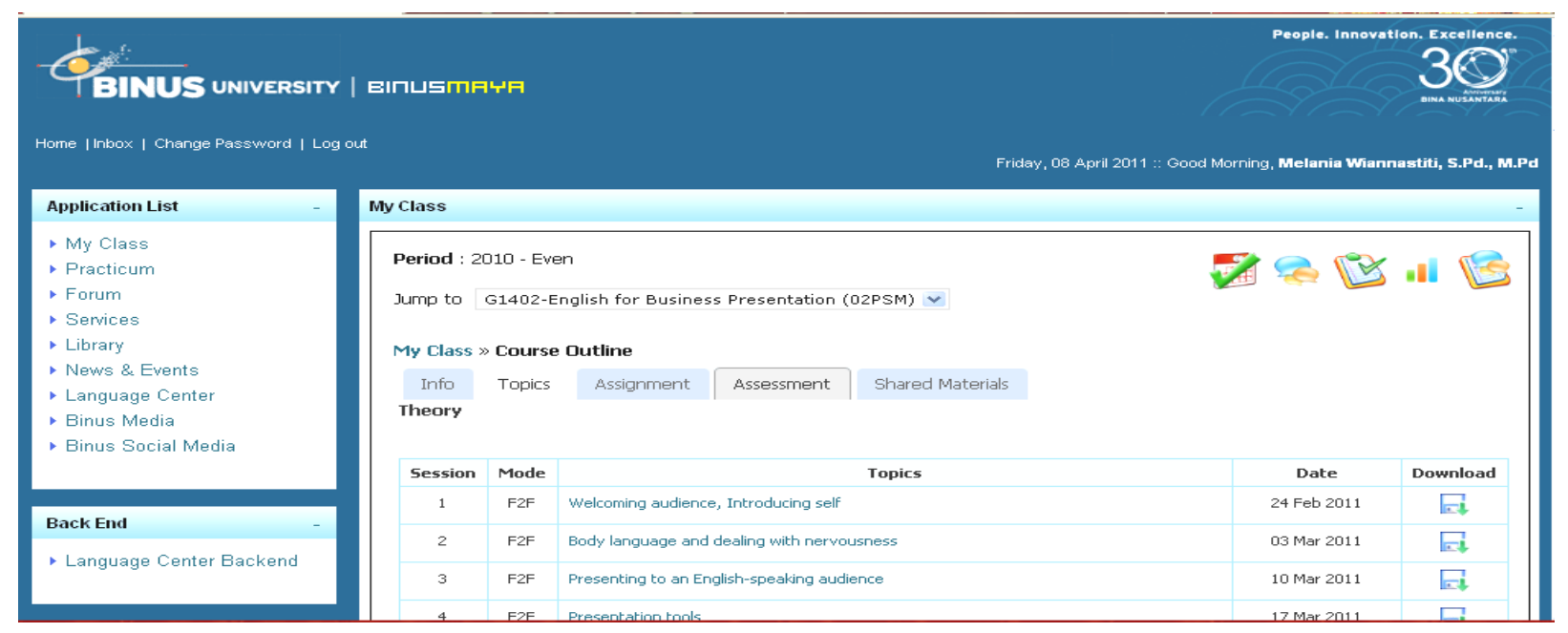

Figure 1 Binusmaya forum

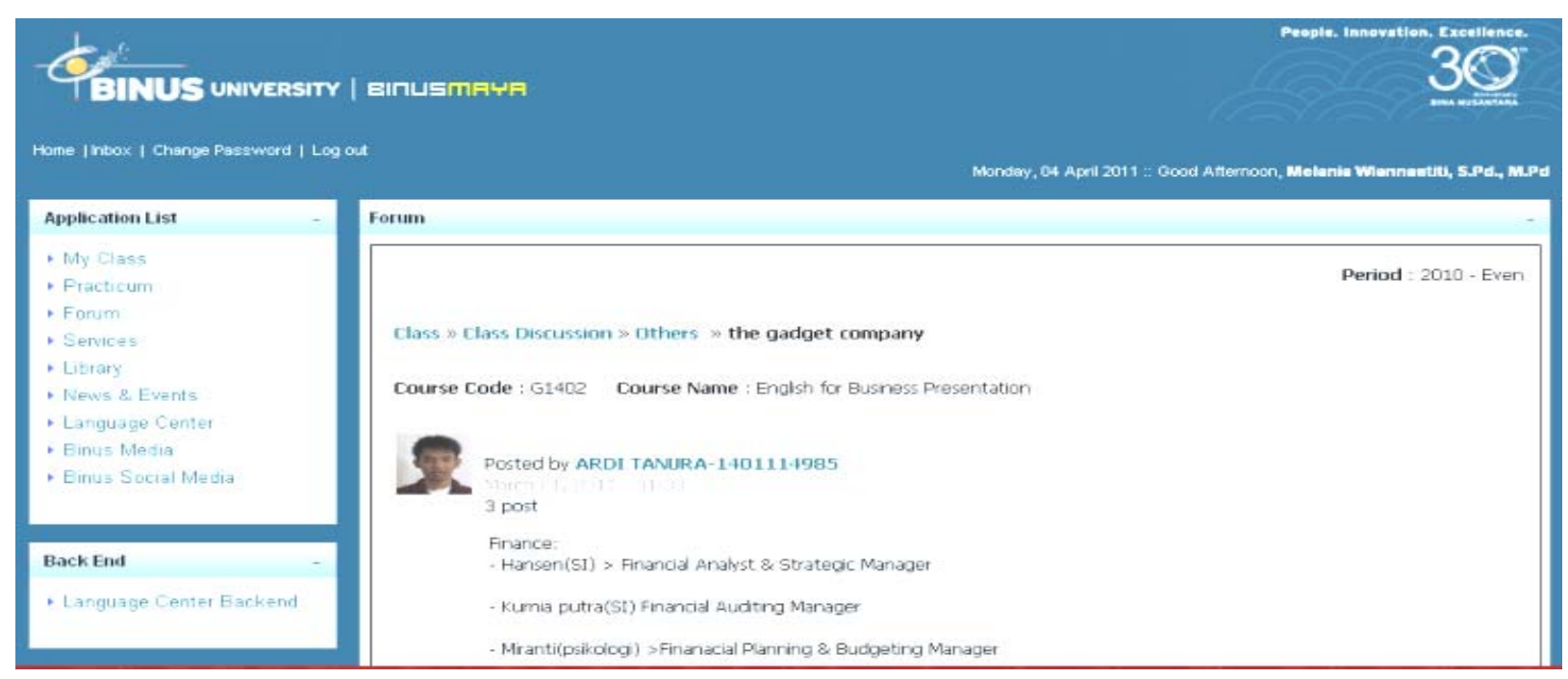

Figure 2 Binusmaya forum 
Binusmaya forum (as in Figure 2) is the room provided in Binusmaya where lecturers and students who take the same lectures either in the same class or parallel classes are able to communicate outside the classroom. It also provides rooms for lecturers and students to discuss some topics concerning with the lecturers they learn as well as uploading and downloading assignments.

Since there are some activities the students have to do, this paper also describes the multichannel learning approach to cover all activities the students have to do. The activities done by the students will be described in detail in the following discussion.

\section{METHOD}

This paper employs library research in which the writer compares some theories of method of teaching especially method for handling big classes. One method of teaching chosen is cooperative learning, and the qualitative method is used to describe the method used in teaching big classes in English.

\section{DISCUSSION}

As it has been mentioned previously that BINUS University carries out general English for all students. The discussion here mainly discusses about the method used to teach English at BINUS University with normally big classes by using cell group and is supported by Binusmaya.

\section{General English at BINUS University}

As a compulsory lecture for undergraduate students at BINUS University, General English is divided into three lectures; English Entrant, English in Focus and English Savvy. The target of them is the same level of English IBT TOEFL which equals to 500 score PBT TOEFL. Before new students enter the university, they have to join English pre test using PBT TOEFL test like. Their score determines in which level they have to join. Only the ones whose score are under 500 have to join English Entrant. The ones who get 500 or more score have to join the different programs called English Business Presentation. Therefore, the students are homogenous.

The number of students in English Entrant class is more than 50 per class and normally about 60-70 students. Limited time is 100 minutes per session, 13 sessions and five skills to learn push a lecture to use a certain method to reach the learning outcomes. One method to offer is cooperative learning in which the students in a class are divided into groups of five.

\section{Cell-Group Method}

Cell group method is a adapted from cooperative learning method, in which a class is divided into groups, puts the students as the center of attention in learning process. This method is used in English Entrant classroom. In the classroom, students are asked to make groups of five and it is called a cell group. Each cell group has a leader and four members. The purpose of choosing group of five is that it is not too big number, which means that each member has bigger opportunity to share ideas in the cell group rather than if the number is more than five.

One advantage of creating is that it is easy to control their attendance in the classroom as student's attendance is one of the requirements to determine whether they are allowed to join the final examination or not. In the classroom, they are asked to sit always in the group; therefore it is easier for the lecture to check their attendance. It is also used to eliminate students to cheat. 
Since the language skills to learn cover four skills; listening, reading, writing and speaking for business, cell groups have important role to develop the members to reach the learning outcomes. Each cell group is directed to multichannel learning with different activities of each skill. The learning activities for each group are cell group discussion, cell group review, cell group presentation and self access learning. Those activities are done in multi channel learning by using Binusmaya, Binusmaya forum, Self-Access Learning Laboratory and email. By using multi channel learning, each cell group does many activities outside the classroom. The detail of the cell group activities for each skill is as follows:

\section{Listening}

There are many ways to do for cell groups for listening. Firstly, each member is assigned to practice listening in self access learning laboratory. The laboratory provides the material for listening and can be accessed anytime at the working hours. After they finish doing it in the lab, the administrator will sign the report form provided by the lecture. Secondly, each member of group practices listening at home or in group if they have the audio.

Thirdly, after listening to the audio, each cell group has to discuss the answer and get the explanation of the answer. Fourthly, if all members do not know the answer, or have no idea about it, they can ask that question in Binusmaya forum, so other groups, either in the same class or other parallel classes can give the answer and discuss about it. Then, every week, the leader has to make a short report about their activities in the report form provided.

\section{Reading}

In reading, each member of the groups has to read the material in the printed material from text book. After reading, they have to meet in cell group to discuss about reading texts, including new vocabularies, the main idea and the answer of the questions. They are asked to write problems they face during the discussion such as if all members do not know the correct answer or if they do not know the idea of the reading texts. Then, they have to write the problems in Binusmaya forum and ask other groups to share ideas and discuss the answer together.

\section{Writing}

In writing, during a semester, the students are asked to write three short essays. Lecturer provides the topic of writing and students are asked to choose three of them. Every member of cell groups is asked to peer-check the writing works before they hand them in to the lectures. They are asked to hand their work in through email or Binusmaya. The lecturer will discuss some of the writing tasks in the classroom and asks all students to review and learn from the tasks discussed.

\section{Speaking}

Since the topic of speaking is Business English, each cell group is asked to work together in cell group to prepare their speaking. Most of the topics for English Entrant are business telephoning, business negotiation and Business presentation, so they are asked to do role playing. They are asked to perform speaking in cell group in front of the class while other cell groups have to give developing comments.

\section{Lecturer's Role in the Teaching Learning Activities}

Almost all of learning processes are being oriented to the cell groups and to the development of each member in the cell groups; therefore the lecturer has the role as organizer, prompter, resource, moderator, and assessor. According to Harmer (2002), as an organizer, what a teacher has to perform 
is that of organizing, students to do various activities, by giving information, put them into pair or groups, and get the students involved. For the cell group activities, lecturer is an organizer. It means that a lecturer has to organize the activities either in or out of the classroom.

In the speaking activities, when students are asked to do role playing, a lecturer has a role to be the one to prompt the students when they get lost in the middle of the activities. It is a kind of helping the students to think creatively. In writing activities, even each cell group is asked to do peer check and group check; they still need a lecture to be the resource of information. In class discussion for listening and reading, a lecturer has a role as the moderator of the group discussion. Each cell group needs to give ideas about reading and listening assignments in the classroom. As the assessor, a lecturer has the role to evaluate the students' performance especially in presentation as well as the assessor in writing.

By having the roles, a lecturer does not need to teach in the classroom, but mainly ask the students to work in the cell group. When they have problems they can discuss in the classroom. Therefore, classroom is mainly for class discussion where the lecturer becomes the moderator and for speaking assessment and performance in which the lecturer becomes the assessor.

\section{Evaluation}

To control the cell group activities outside the classroom, each cell has to make a report in weekly base. They have to write in detail about the activity they learn. The report consists of the time of activities, the activities they do and the problem they face. From the report, the lecture can discuss in the classroom and find the solution to the problems. The example of the report can be seen in appendix 1. English Entrant evaluation carried out in three ways, they are: (1) listening and reading, they will do scheduled IBT TOEFL test in the laboratory, by using online test. Therefore system will give them score automatically; (2) for speaking section, a lecturer can take the score from the performance of each cell group in the classroom; and (3) for writing section, a lecturer uses their writing work after being checked in each group. A point plus will be given to the cell groups which have many discussions out of the classroom which can be proved by weekly report.

\section{CONCLUSION}

The cell group method is suggested to lecturers at BINUS University to teach English Entrant classes since it offers a method which supports a lecture to do class management easier, especially the students attendance and also supports a lecturer to note the students progress. The most important thing of cell group method is it gives a room for the students to hold cell group discussion in which each student has bigger opportunity to develop themselves by a support from his/her cell group members to reach the objective of the teaching learning. It is strongly suggested for lecturers who teach big classes to use this method or to modify it to meet the need of the students.

\section{REFERENCES}

Brown, D. (2001). Teaching by principles: An interactive approach to language pedagogy (2nd ed.). New York: Addison Wesley Longman.

Harmer, J. (2001). The practice of English language teaching. Essex: Pearson Education. 
Ives, S. M. (2000). A survival handbook for teaching large classes. Retrieved on April 7, 2011, from: http://teaching.uncc.edu/articles-books/best-practice-articles/large-classes/handbook-largeclasses

Richards, J. C., \& Renandya, W. A. (Eds). (2002). Methodology in language teaching: An anthology of current practice. New York: Cambrige University Press.

\section{APPENDIX}

Appendix 1: Example of Weekly Report Form

\begin{tabular}{|c|c|c|c|c|}
\hline Class: 02PAO & $\begin{array}{l}\text { Group: } \\
01\end{array}$ & Leader: & $\begin{array}{r}\text { Member: } 1 . \\
2 .\end{array}$ & \\
\hline Day/date & Time & Activities/ description & Participants & Notes \\
\hline $\begin{array}{l}\text { Tuesday } \\
12 \text { October } 2010 \\
\text { Wednesday } \\
13 \text { Oct } 2010\end{array}$ & $\begin{array}{l}11.00- \\
11.00 \\
14.00- \\
15.00\end{array}$ & $\begin{array}{l}\text { Listening (laboratory 730) } \\
\text { Listen to IBT listening mini test } 1 \\
\text { Speaking } \\
\text { Making dialogues and practicing } \\
\text { about telephoning. } 1 \text { dialogue for } 2 \\
\text { members and 1dialogue for } 3 \\
\text { members }\end{array}$ & $\begin{array}{l}\text { All } \\
\text { All }\end{array}$ & $\begin{array}{l}\text { Difficulties in } \\
\text { catching the } \\
\text { ideas. } \\
\text { No }\end{array}$ \\
\hline \multicolumn{3}{|l|}{ Leader's Signature } & \multicolumn{2}{|c|}{ Lecture’s Signature } \\
\hline Name & & & Name & \\
\hline
\end{tabular}

